\title{
A New Paradigm of Learning through Information Management Systems in Higher Education
}

\author{
Submitted 20/03/20, $1^{\text {st }}$ revision $14 / 04 / 20,2^{\text {nd }}$ revision $19 / 06 / 20$, accepted $30 / 07 / 20$
}

\begin{abstract}
Nur Aedi ${ }^{1}$
Abstract:

Purpose: The study aims to address the low student motivation in learning and the lack of creativity, especially during lectures.

Design/Methodology/Approach: The research used the qualitative descriptive research approach to determine the effectiveness of learning through an online instructional system. The participants comprised of 145 students of the Educational Administration study program.

Practical Implications: The research findings indicated students' increased interest in conducting the discussions with the lecturers and the other students, proving the effectiveness of information systems in learning. With the challenges associated with mobility coupled with the convenience information systems present like almost unlimited access to academic information, the future of education will be inseparable from information systems. Before the current situation, online learning thought it had been around for years, it was unpopular, mostly it was used in developed countries, but currently, the abrupt global confinement has led to online schooling and learning as a new norm at a national level and also turning out to be a global trend, influencing the mode of learning and delivery in developing countries, such as Indonesia.

Originality/Value: There are several studies conducted on information management systems in higher education learning, but its adoption in mainstream learning systems in higher education has been treated with reservations' policymakers in many countries. This study's value is to draw more attention to the empirical proof effectiveness of these systems in higher learning to stimulate policy shifts towards its adoption as mandatory mainstream learning systems even after the social lockdown measures are currently gripping the world.
\end{abstract}

Keywords: Educational, management, and learning management systems.

\section{JEL Code:}

Paper Type: Research study.

\footnotetext{
${ }^{1}$ Indonesia University of Education, email: nuraediupi14@gmail.com or nuraedi@upi.edu
} 


\section{Introduction}

Educational management as a study discipline is one of the courses that provide students with the knowledge and understanding of the various theories and concepts of managing education. The basic idea of the educational management gives an overview of the educational management processes, characteristics of management and education, educational management strategies, innovations in the field of the workforce, educational management systems, curriculum innovation, learning innovation, innovation and learning through information technology (Lampard, 2002).

The Indonesia University of Education has been harnessing information, communication, and technology (ICT) to support learning activities, such as elearning or distance learning (Jung, 2002). The core of the Indonesia University of Education (UPI) is education as a discipline and profession. It needs to continually reinvigorate its study courses and programs as the country's vanguard of education development. Breakthroughs and reforms in education are required for competitive global level education to take root (Idowo, Abimbola, and Adagunodo, 2004). Information and communication technology (ICT) are now touched and are already necessities that support most people's livelihood in many ways; students are no exception (Toprakci, 2006).

In the decision of the President of the Republic of Indonesia Number 8 in 2006 about the Board's public information and communication technology States that "information and communication technology (ICT) is the main pillar of the development of human civilization today and is an important means in the process of transformation into a developed nation." More on that note, the decision of the Ministry of National Education No. 107/U/2001 states the position of ICT in the utilization of e-learning as a complementary learning process to the conventional learning process (Hafkin, 2002).

Studies in the field of Educational Management in higher education learning have been conducted through face-to-face sessions in a classroom setting, giving time to students who also need time and space without limitation to only scientificeducational management and learning (Davis, 2003). in other words, profoundly implementing online learning, whose objective is to seek:

1) utilize shared learning resources that will ultimately improve the quality of higher education and expand access to education in Indonesia;

2) attain equitable understanding of Education Management as a field of study to build a new phase education in Indonesia that excels in Online learning;

3) increase the students' interest in learning Educational Management, which will ultimately improve student academic achievement in the broader scope (Culp, Honey, and Mandinach, 2003). 


\section{The Study}

Based on the above, this research aims to identify innovation with learning management systems, thorough teaching strategies. The specific objectives for conducting this research were: (1) to increase students motivation in studying the course of Educational Administration and Management; (2) to identify suitable teaching strategies, methods and tools that can be used by teachers in the teaching process and (3) to stimulate more discussion between lecturers and students in the Educational Administration and Management course at the Indonesia University of Education.

This research sample was composed of 145 students $(\mathrm{N}=145)$ taking courses in the Educational Administration and Management Program at the Indonesia University of Education, particularly from the Faculty of Mathematics, the Faculty of Sports Science, and Faculty of Business Management.

The research method was represented by an analysis based on a survey and whose instrument was composed of 25 multiple-choice items, grouped in the categories of educational administration and management objectives toward students, the transforming learning management systems from the lecturer to students, responding and best the student appreciation, exactly improving learning strategies used by learning management systems (Teo, Lee, and Chai, 2008).

The data analysis techniques in this survey was by triangulation of a combination of results from observations carried out during direct interviews and studying documentation from the implementation of students' learning process from members and users of the study's online learning (Cloke and Sharif, 2001). Online learning courses in Education Management had inputs that included topics on human resources, infrastructure, planning of learning, and information management (Vacc and Bright, 1999).

Other aspects in the Input were the planning process of systematic learning, translating learning principles into learning design and learning materials through 1) methods that empower students to achieve, 2) using specific learning objectives, and 3 ) interactive and learning activities in the learning environment (Smeets, 2005). Planning the study is divided into components like the program map, delivery systems, and time. This survey was conducted on 145 Education Management students from different faculties such as the Faculty of Mathematics, the Faculty of Sports Science the faculty of Bussiness Management. The components of learning management systems include learning interactions, teaching, learning content, and teaching interactions, as in Figure 1.

Design of the online learning components focused on the main aspects that include delivery mechanisms, learning content, and interactions in the form of learning scenarios that had already been designed before the start of the teaching and 
learning. The next step in the planning needs to be prepared, as illustrated in Figure 2 .

The delivery system in Online learning blended learning, face-to-face collaboration, videoconferencing as well as web-based applications. The delivery system is divided into periods to balance the Online learning (Jaffer, Ng'ambi, and Czerniewicz, 2017). Face-to-face collaborative learning was synchronized with virtual learning material in the form of emails, forum discussions, web-based videos, and other tasks.

Figure 1. Input Online Learning

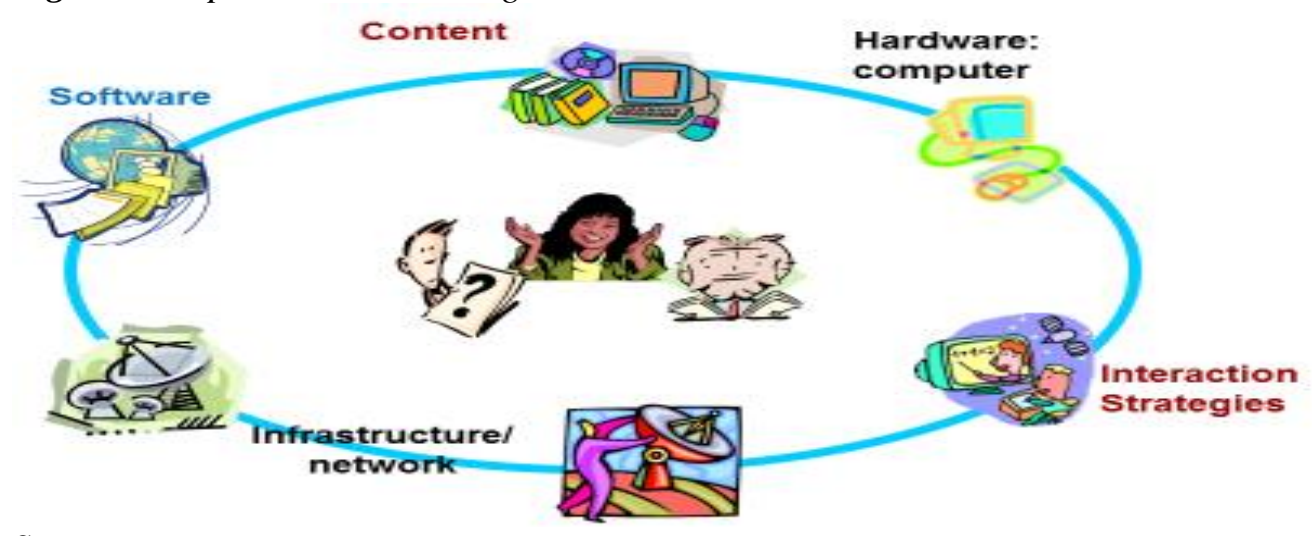

Source: Own.

Figure 2. Input Online Learning

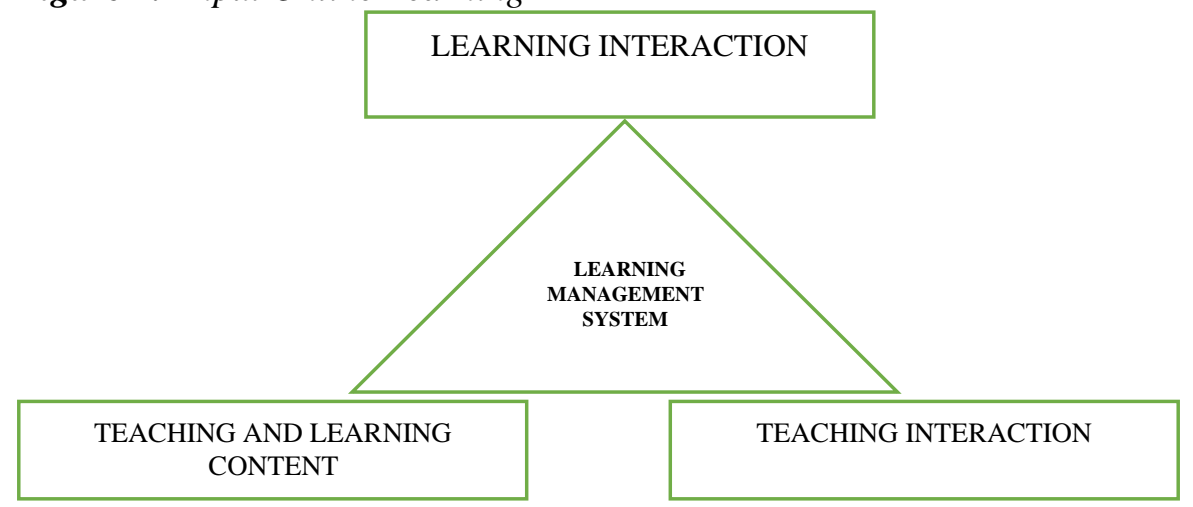

\section{Source: Own.}

Aspects of Input on Online learning already fulfilled and implemented as one of the fulfillment of the implementation of the effectiveness Online learning systems (Strudler and Wetzel, 1999). 
Figure 3. Line Learning Program Map

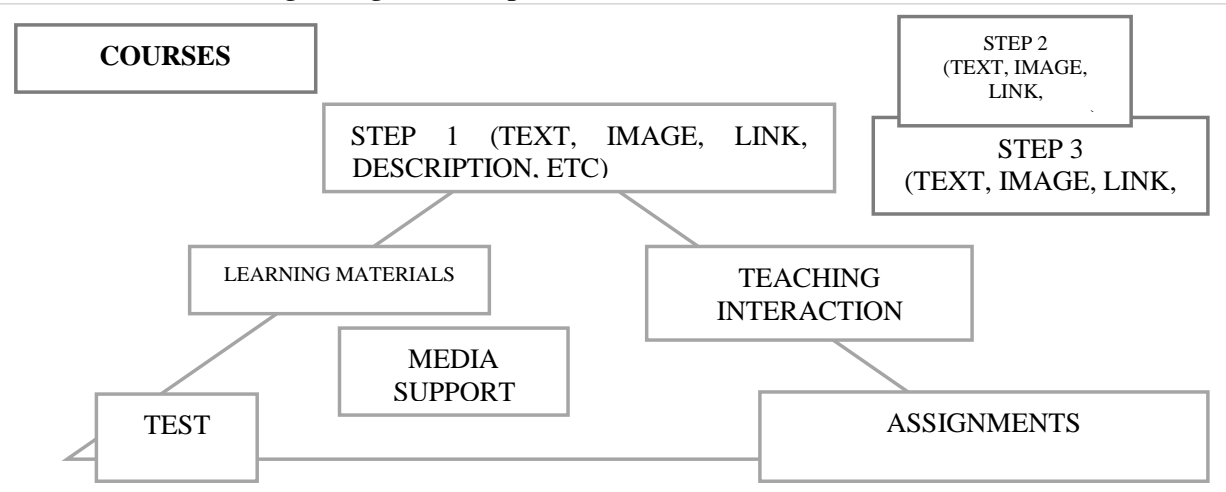

Source: Own.

Figure 4. Line Learning Program Map
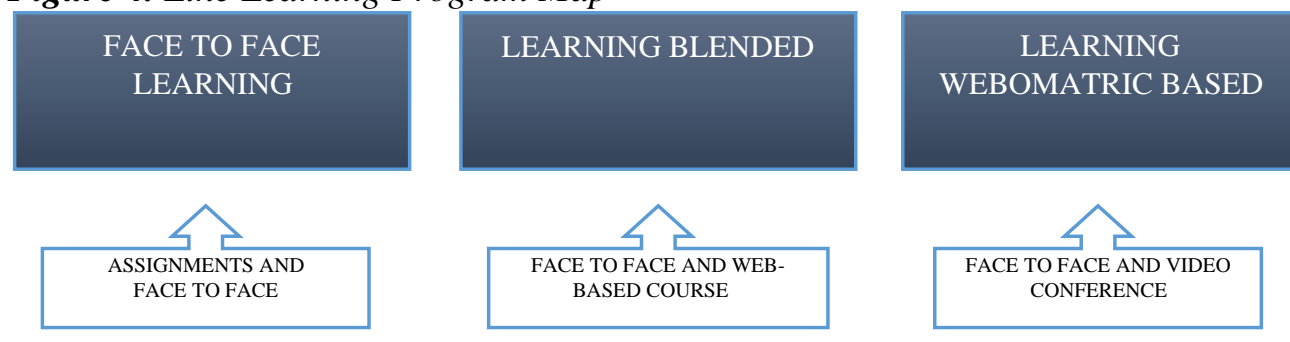

\section{LEARNING MANAGEMENT SYSTEMS INTERACTION}

Source: Own.

\section{Findings and Discussion}

\subsection{Online Learning Implementation aspects of Input}

In Online learning for this study, aspects of the Education Management were the Input. They include human resources, infrastructure, planning of learning, and information, following visualization aspects of Online learning input (Shakeshaft, 1999).

Another input aspect is the planning process that is systematic learning that translates the principles of learning into the learning design and learning materials: 1) method that empowers students to achieve nothing specific, 2) using particular learning objects, 3) through several activities of learning and interaction in a learning environment (Rovai, 2002). Planning study is divided into four components: the study of aspects of map programs, delivery systems, and time. The Input of this survey is all of the students that get the course of education. Input in this study is that all students follow Education Management courses entirely followed by two faculties, which is the Faculty of Business and Economics, and the faculty of 
education at the department of special education follow this course many 145 people.

Design of an Online learning component focused on three main aspects, namely, the delivery mechanism, as well as the learning object content or interactivity in the form of activity or type of learning scenarios already designed before the start of the teaching-learning (Nachmias, Mioduser, and Shemla, 2019).

Courses are mapped into several rounds; each round of learning is filled with a variety of learning methods tailored to the concept Online (Nooriafshar, 2008). Processes were undertaken in online learning; there are text lessons and images as a form of visualization, training, video, audio, or clip charts. While the process of discussion in Online learning using a discussion forum with chat, teleconference, face to face, and email. Besides, the task in Online learning, like concluding or make the article (Oliver, 2008). The delivery system in Online education, blended learning, collaboration is face-to-face, blended videoconferencing as well as blended web-based (Banu Kamal, and Banu, 2010). The delivery system is divided into a certain period to balance the learning Online. Collaboration learning between faceto-face and virtual synchronous learning material, in the form of emails, forum discussions, and tasks directly collaboration web-based videos. Aspects of Input on Online learning are already fulfilled and implemented as one of the effectiveness of online learning systems practice (Peeraer and Petegem, 2009).

\subsection{The Implementation of the Online Aspects of the Learning Process}

Figure 4 above explains the implementation of the Online learning courses on Education Management using a blended learning approach to the pull and the push model (Robertson and Whiting, 2008). On this learning, approach to synchronize all learning resources and focus on a point that is on the web with the description that the process of learning Online lecturers or experts being a facilitator and motivator. Other facilities in the form of a learning book in the library created an e-book so that access is easy. Assignments and exams that are usually using paper print outs, Online learning in students can access them on the web with a certain amount of time has been set. The Online learning process follows the planning so that the level of the successful learning process is met. The learning process in the implementation of active Online learning, the absence of any technical error due to already planned carefully (Tracey, 1999).

\subsection{The implementation of the Online Learning aspects of the Output}

Students who follow the whole or a portion of the Online classes have much better performance than the average compared to those who do similar learning through face-to-face in a classroom (Twigg, 2003). The evaluation of the learning outcomes of students involved in Online learning exceeded the results of the students receiving face-to-face instruction only (Van der Wende and Beerkens, 1999). 
However, the interpretation of these results should also consider that online and face-to-face conditions are generally different in several dimensions, including the amount of time spent by students in the task (Warwick, 1999). Therefore, the advantages of Online learning conditions observed in a product of the aspects of the treatment of states other than pure teaching of delivery media (Wilson, Qayyum, and Boshier, 1998). The Output of the Online learning courses on educational management is evidenced by the number of visits of students on the web, quite a lot of discussion forums on the internet are two-way and recommended new theories outside the lecture material. The value of students' exam results has a value higher than the test in class. With the phenomenon of Online learning outputs, findings can be said to be effective (Rava and Rossbacher, 1999).

\section{Conclusion}

The lecture current of paradigm should change in designing and implementing the learning process. The educational model that evolved at this time uses learning information systems as a supplement to face-to-face lectures. Students can construct their knowledge acquired through experience alone. The lecturer's changing role primarily determined the successful implementation of Online learning in lectures and became a facilitator, motivator, and evaluator. The process must be designed Online courses with more creative and as attractive as possible and developing process of the lecture because, thereby, the learning process does not just happen in the classroom with a schedule which is already specified can happen anywhere, anytime, and with anyone.

Elements such as video or quizzes Online affect the amount learned by students in Online classes (Pelgrum, 2001). Research does not support the use of multiple learning practices, which is often recommended. More media involvement in applying Online does not seem to reinforce learning. Nevertheless, the method of administering Online quizzes is more effective than giving homework due can be limited by a particular time. Discussion forums in Online classes more broad and profound because students can go looking for references on the internet.

Online learning can be strengthened by providing students with the opportunity to interact with media control learning and encourage reflection on students when doing Online learning. Online learning indicates that the manipulation of the trigger or student activities student reflection and understanding of effective independent monitoring at the time of the Online learning students as individuals. Provide guidelines on learning for student groups seem more successful than it does not use the same mechanism for individual students. When a group of college students learning together online, supporting devices such as the question of the guidelines generally affect how students interact but do not affect the amount they are learning.

\section{References:}


Cloke, C., Sharif, S. 2001. Why use information and communication technology in schools? Some theoretical and practical issues. Journal of Information Technology for Teacher Education, 10(1-2), 7-18. Retrieved from: http://www.triangle.co.uk/jit/index.htm.

Culp, K.M., Honey, M., Mandinach, E. 2003. A Retrospective in Twenty Years of Educational Technology Policy. Retrieved from: http://www.nationaledtechplan.org/ participate/20years.pdf.

Davis, N., 2003. Technology in teacher education in the USA: What makes for sustainable good practice? Technology, Pedagogy, and Education, 12(1), 59-84. Retrieved from: http:// www.triangle.co.uk/jit/index.htm.

Federal Republic of Nigeria. 2001. Nigeria National Policy for Information Technology (IT). Retrieved from: http://www.nitda.gov/docs/policy/ngitpolicy.pdf.

Hafkin, N. 2002. Gender issues in ICT policy in developing countries. An overview. United Nation's Division for the Advancement of Women (DAW) Expert Group meeting on Information and Communication Technology and their impact on and use as an instrument for the Advancement of Women, Seoul, Republic of Korea. http://www.apc.org/english/capacity/policy/mmtk_gender_ictpol_hafkin.pdf.

Idowo, P.A., Abimbola, O.I., Adagunodo, E.R. 2004. A Comparative Study of Information and Communication Technologies at Higher Educational Institutions in Africa: Case Studies from Nigeria \& Mozambique. Journal of Information Technology Impact, 4(2), 67-74.

Jaffer, S., Ng'ambi, D., Czerniewicz, I. 2017. The role of ICTs in higher education in South Africa: One strategy for addressing teaching and learning challenges. International Journal of Education and Development using Information and Communication Technology (IJEDICT), 3(4), 131-142.

Jung, I. 2002. Issues and Challenges of Providing Online In-services Teacher Training: Korea's Experience. Retrieved from: http://www.irrodl.org/content/v2.1/jung.pdf.

Nachmias, R., Mioduser, D., Shemla, S. 2019. Information and Communication Technologies usage by students in an Israfli High School. Retrieved from: http://muse.tau.ac.il/ktl/ICT.pdf.

Nadira Banu Kamal, A.R., Banu, T. 2010. ICT in Higher Education - A Study. Canadian Journal on Data, Information and Knowledge Engineering, 1(1), 12.

National Policy on Information and Communication Technology (ICT) in School Education. Retrieved from: http://www.education.nic.in/secedu/ict.pdf.

Nooriafshar, M. 2008. The Role of Technology based Approaches in Globalizing Education, Anil Varma (Ed). Information and Communication Technology in Education, First edition, Icfai University Press, Hyderabad, p. 53.

Oliver, R. 2008. The Role of ICT in Higher Education for the 21st Century: ICT as a change agency for education, Anil Varma (Ed). Information and Communication Technology in Education, First edition, Icfai University Press, Hyderabad, p. 13.

Pearson, J. 2003. Information and communication technologies and teacher education in Australia. Technology, Pedagogy and Education, 12(1), 39-58. Retrieved from: http://www.triangle.co.uk/jit/

Peeraer, J., Petegem, P.V. 2009. Factors Influencing Integration of ICT in Higher Education in Vietnam. Retrieved from: http://www.google.co.in/search?q=PeopleICT-.

Pelgrum, W.J. 2001. Obstacles to the integration of ICT in education: results from a worldwide educational assessment. Computers and Education, 37, 163-178.

Pope, C., Golub, J.N. 2000. Preparing tomorrow's english language arts teachers today: principles and practices for infusing technology. Contemporary Issues in 
Technology and Teacher Education, 1(1). Retrieved from:

http://www.citejournal.org/vol1/iss1/currentissues/english/article1.htm

Pole, C., Lampard, R. 2002. Practical Social Investigation. Qualitative and Quantitative

Methods in Social Research. Harlow, Printice Hall.

Rava, S., Rossbacher, B. 1999. Teaching and technology: a new course for TA development. ADFL Bulletin, 30, 63-71.

Robertson, C., Whiting, W. 2008. Weblogs: Building an Academic Family in Cyberspace', Anil Varma (Ed). Information and Communication Technology in Education, First edition, Icfai University Press, Hyderabad, p. 133.

Robertson, S., Calder, J., Fung, P., Jones, A., O’Shea, T. 1995. Computer attitudes in an English secondary school. Computers \& Education, 24, 73-81.

Roblyer, M.D. 2002. Integrating Educational Technology into Teaching (3rd ed.). Upper Saddle River, NJ, Prentice Hall.

Rogers, M.E. 1995. Diffusion of Innovations (4th ed.). New York, The Free Press.

Rovai, A.P. 2002. Building sense of community at a distance. International Review of Research in Open and Distance Learning, 3(1), 1-16.

Selinger, M., Austin, R. 2003. A comparison of the influence government policy in information and communications technology for teacher training in England and Northern Ireland. Technology, Pedagogy and Education, 12(1), 19-38. Retrieved from: http://www.triangle.co.uk/jit/.

Schoepp, K. 2005. Barriers to technology integration in a technology-rich environment. Learning and teaching in higher education: Gulf perspectives, 2(1), 1-24.

Schrier, L.L. 2001. Developing precollegiate foreign language teachers: an overlooked mission of foreign language departments. ADFL Bulletin, 32 (3), 71-78.

Sekaran, U. 2003. Research Methods for Business: A Skill-Building Approach (4th ed.). Singapore.

Shakeshaft, C. 1999. Measurement issues with Instructional and Home Learning Technologies. Paper presented at the Secretary's Conference on Educational Technology.

Shukre, A. 2008. The Future of Online Education in India', Anil Varma (Ed). Information and Communication Technology in Education, First edition, Icfai University Press, Hyderabad, p. 91.

Sicilia, C. 2005. The Challenges and Benefits to Teachers' Practices in Constructivist Learning Environments Supported by Technology. Unpublished master's thesis, McGill University, Montreal.

Smeets, E. 2005. Does ICT contribute to powerful learning environments in primary education? Computers and Education, 44(3), 343-355.

Sooknanan, P. 2002. Attitudes and perceptions of teachers toward computers: the implication of an educational innovation in Trinidad and Tobago. (Doctoral dissertation), Bowling Green University.

State Planning Organization (SPO). 2006. Information Society Strategy 2006-2010. Ankara, State Planning Organization. Retrieved from: http://www.bilgitoplumu.gov.tr/eng/docs/Information\%20Society $\% 20$ Strategy_Turkey.pdf.

State Planning Organization (SPO). 2008. OECD-IT Policy Questionnaire 2008-Turkey. Retrieved from: http://www.bilgitoplumu.gov.tr/yayinlar.asp.

Strudler, N., Wetzel, K. 1999. Lessons from exemplary colleges of education: factors affecting technology integration in preservice programs. Educational Technology Research and Development, 47(4), 63-81. 
Teo, T. 2008. Pre-service teachers' attitudes towards computer use: A Singapore survey. Australasian Journal of Educational Technology, 24(4), 413-424.

Teo, T., Lee, C.B., Chai, C.S. 2008. Understanding pre-service teachers' computer attitudes: Applying and extending the Technology Acceptance Model (TAM). Journal of Computer-Assisted Learning, 24, 128-143.

Tondeur, J., van Braak, J., Valcke, M. 2007. Curricula and the use of ICT in education: Two worlds apart. British Journal of Educational Technology, 38(6), 962-976.

Toprakci, T. 2006. Obstacles at integration of schools into information and communication technologies by taking into consideration the opinions of the teachers and principals of primary and secondary schools in Turkey. Journal of Instructional Science and Technology (e-JIST), 9(1), 1-16.

Tracey, M. 1999. Whatever It Is, It Is Ours to Think About. Communications Issues in the 1990s: A Philosophical Framework for the IIC. In R. Winsbury and S. Fazal (eds.) Vision and Hindsight: The First 25 Years of the International Institute for Communications. London, John Libbey and Company, 210-235.

Twigg, C.A. 2003. Improving Learning and Reducing Costs: New Models for Online Learning. Educause Review Article.

Vacc, N.N., Bright, G.W. 1999. Elementary preservice teachers' changing beliefs and instructional use of children's mathematical thinking. Journal for Research in Mathematics Education, 30(1), 89-110.

Van der Wende, M., Beerkens, E. 1999. An international orientation of institutional strategies and governmental policies for the use of ICT in higher education. Interactive Learning Environments, 7(2-3), 283-321.

Wilson, M., Qayyum, A., Boshier, R. 1998. World Wide America? Think globally, click locally. Distance Education, 19, 109-123.

Yildırım, S. 2000. Effects of an educational computing course on preservice and inservice teachers: a discussion and analysis of attitudes and use. Journal of Research on Computing in Education, 32(2), 479-495. 